\title{
Why Might People Donate Tissue for Cancer Research? Insights from Organ/Tissue/Blood Donation and Clinical Research
}

\author{
Renata E. Axler ${ }^{a}$ Rob Irvine ${ }^{a}$ Wendy Lipworth ${ }^{a}$ Bronwen Morrella \\ Ian H. Kerridge $\mathrm{e}^{\mathrm{a}, \mathrm{b}}$ \\ ${ }^{a}$ Centre for Values, Ethics and the Law in Medicine, University of Sydney, and ${ }^{b}$ Haematology Department, \\ Westmead Hospital, Sydney, Australia
}

\section{Key Words}

Biobanking $\cdot$ Cancer research $\cdot$ Consent $\cdot$ Motivation .

Organ donation $\cdot$ Research participation $\cdot$ Tissue donation $\cdot$

Tumour banking $\cdot$ Gift relationship

\begin{abstract}
Little is known about why patients with cancer do or do not donate their biopsied/cancerous tissue to research. A review of the literature on motivations to participate in clinical research and to donate tissues/organs for therapeutic use may provide some insights relevant to tumour banking research. While more research is necessary, a better understanding of the factors that motivate patients to give or refuse consent to tumour banking may ultimately improve consent practices, public trust and donation rates.
\end{abstract}

Copyright $\odot 2008$ S. Karger AG, Basel

\section{Introduction}

Tumour banks are generally regarded as an essential resource for research into the biology of cancer [1-3]. Collections of tissue, usually removed in the course of diagnostic or therapeutic procedures, enable studies to be carried out linking abnormalities in the tissue to disease aetiology, prognosis and treatment responsiveness. Moreover, storage over time enables laboratory findings to be correlated with disease progression and patient response to treatment, as well as enabling as yet undiscovered techniques to be applied in the future to previously collected samples.

When tumour samples are collected from patients in the course of diagnosis or therapy, patients are asked whether they would like to donate their tissue sample to research. Consent to this donation means that their tissue sample will be placed in a tissue or tumour bank. There are many kinds of tissue banks organised according to a number of demographic factors such as age, geographic location, cultural groups or disease groups.

For many years, the secondary use of diagnostic and therapeutic tissues in research did not cause much ethical concern. There was little specific regulation, and consent for tumour banking research - if obtained at all - was obtained in a 'blanket' fashion, asking patients to authorise the use of their tissues for any kind of research. This approach was widely supported by researchers and was not illegal [3]. The ethical requirement that consent to research be 'specific' was interpreted broadly and waiver criteria for consent, such as 'inconvenience' and 'public interest', were applied liberally $[3,4]$. Recently, however, controversy has arisen about the practices of collecting, storing and using human tissue for research purposes. This controversy is due, in part, to a series of media exposures of 'scandalous', non-consensual retention of organs from post-mortem examinations in several coun-

\section{KARGER}

Fax +4161306 1234

E-Mail karger@karger.ch

www.karger.com (c) $2008 \mathrm{~S}$. Karger AG, Basel

$1015-2008 / 08 / 0756-0323 \$ 24.50 / 0$

Accessible online at:

www.karger.com/pat
Dr. Renata Axler

Centre for Values, Ethics and the Law in Medicine

Level 1 Medical Foundation Building K25, University of Sydney

Sydney NSW 2016 (Australia)

Tel. +61 29036 3405, Fax +61 29036 3436, E-Mail renata_axler@hotmail.com 
tries, including the United Kingdom and Australia $[5,6]$.

Insofar as donation is offered, participation rates are generally high and few patients refuse to have their tissue stored. Consent to tumour banking research is still an ethical concern however, particularly regarding the manner in which consent should be obtained, the meaning and implications of consent (specifically whether recurrent project-specific consent is needed) and whether, and to whom, tissue-derived data can be disclosed [2, 3, 7-9]. Other ethical issues relate to whether tissue can be owned and sold, since it is becoming clear that commercial use of tissue is unacceptable to some tissue donors [3, 10-12] and whether tissue is 'sacred' and, therefore, different to other kinds of health information, such as medical records and genetic databases [13]. Finally, there is discussion about whether the laboratory-based epidemiological techniques typically used in 'tissue banking research' are well founded scientifically and whether, therefore, such research - which poses a small risk to participants - is ethical [14].

Given these ongoing and somewhat intractable controversies, we believe that it is important to understand not only the scientific, ethical and legal issues raised by tumour banking, but also the reasons why people may choose to donate or to refuse such donation. If one is to truly respect a donor's autonomy, for example, then one needs to use tissue in a manner that is consistent with what is important to them, their intentions, imagined goals, interests and choice of action. While some empirical research into the values of donors has been carried out [15-23], there has been very little research into what motivates patients with cancer to donate their tissue. We offer critical evaluation of the published literature and provide some conclusions based on that literature that may provide a new understanding of a rapidly moving field.

The meaning, nature and origin of human motivation is a complex philosophical, psychological and sociological issue, with motivations being defined in terms of, among other things, discourses, internal states and needs [24-27]. For the purposes of this series of speculations about tumour tissue donation, we have chosen to define 'motivation' simply as the socially shaped reason or reasons one has (or cites) for acting or behaving in a particular way [28]. Using this definition, we have identified a number of reasons that have, or may, be cited for participating, or not participating in tumour banking research, clinical research and live therapeutic (organ/tissue/blood) donation.
In seeking to understand the motivations to donate tumour samples it is worthwhile considering the ways in which tumour banking research is like, and unlike, other forms of voluntarism in medicine, namely the decisions to participate in clinical research and the decision to donate 'live' therapeutic tissue (organs/tissue/blood). If tumour banking is simply a variant of these other practices, then we are likely to already have a good understanding of the issues at stake, and we may already be able to derive processes/practices for increasing rates of donation [29]. If, on the other hand, tumour banking does raise unique issues, then it is important to establish exactly what these may be, so that emerging consent procedures, and regulation more generally, can accommodate them. Understanding motivations to donate tissue may have profound implications for tumour banking research as it is conceivable that the current trend of increasingly stringent privacy and consent requirements may not be consistent with the motivations and beliefs of patients/donors and so may be unnecessary or even counter-productive.

\section{Possible Motivations for Donation of Tumour Samples}

\section{Altruism}

Decisions to participate in acts that are of no immediate benefit to the person such as participating in any kind of research or therapeutic donation are often cited as examples of altruism [30-33]. Altruism refers to voluntarily performed behaviour that intentionally benefits another person without expectation of reward. Several writers suggest that the motivational forces behind altruistic behaviour include internalised feelings of personal obligation. In his analysis of bone marrow donation, Schwartz [34] found that such altruistic behaviour was a function of the person's feelings of moral obligation to carry out this action.

Altruism in the case of tissue donation may be attributed to notions of one's identity as an altruist [35] and may be directed towards specific future patients or family members [36] or more generally towards society. In his study of reasons why new mothers decided to provide placenta, cord tissue and maternal blood to a DNA bank, Barr [37] reports that many mothers donated because they or someone close to them had benefited from research done previously. In this context, the request for tissue for the purpose of biobanking afforded them an opportunity to contribute to research that might one day 
benefit a family member or others. In the case of cancer, donating tumour samples to a research bank may be an opportunity to engage with the 'good' by contributing to cancer research, while receiving some consolation to the solitude and deep pain that is engendered by this illness. In this sense, tumour banking research has much in common with each of the comparators, since altruism is a key motivating factor for those participating in any kind of research $[32,36]$ as well as in therapeutic donation $[38$, 39].

The altruistic forces behind tumour banking may, however, differ from those in some kinds of clinical research and therapeutic donation because the physical risks to tumour tissue donors are relatively small when compared to those who donate solid organs and those participating in clinical research, and therefore demand less of the donor. The decision to donate tissue in tumour banking may require little of the donor in terms of time commitments or harm above and beyond the removal of the tumour for diagnostic or therapeutic purposes. On the other hand, the potential benefits to society are relatively unclear given the open-ended nature of tumour banking research, which may make it less clear to donors why they should participate.

Another factor that may differentiate altruism in the tumour banking setting from altruism in other settings: the fact that what is being given up is diseased tissue (a tumour), rather than one's time, personal comfort and safety, or parts of one's 'healthy' body. While the objects of live organ and tissue donation for transplantation, such as kidneys, livers and blood, are seen as objects of value in society that can give life and save life, to the cancer patient, the tumour could be seen as nothing more than a waste product: a pollutant, or worse, an immanent threat to one's health. Symbolism and ideology surrounding tumours also invoke great anxieties and fears within the person [40]. This negative symbolism may in turn change the nature of altruism since people may not see themselves as giving up anything of value and may not understand the potential value of the tumour to researchers. In the case of tumour banking, while the donation may have little meaning for the donor, the recipient (the researcher) may gain considerable epistemic value from that tissue.

\section{Egoistic Motives and Personal Benefit}

A number of writers have questioned conceptions of altruistic donation, suggesting that patients may donate tissue for 'selfish' reasons, including the desire to affirm ones identity or the expectation that they will benefit per- sonally from the research. Boe and Ponder [41] found that blood donors provided blood with the expectation of something in return. Similarly, Edwards et al. [42] found that in the clinical trial setting, self-interest, rather than altruism, may be a patient's main motive for participation.

Clinical researchers have long recognised that the patient's decision to participate in research can be motivated by, or reflect, egoistic motives. It is recognised that, rightly or wrongly, people may consent to participate in clinical trials because they expect to benefit directly from the research (i.e. the 'therapeutic misconception'). The therapeutic misconception involves a belief that the treatment will be individualised to the subject, overestimations of therapeutic benefits from research participation, failure to perceive that risks from participation in research may be higher than that of therapeutic clinical care, and general misunderstandings of the research design $[30,32,43,44]$. While the therapeutic misconception is much less likely to be a factor in tumour banking research than clinical research, it is still possible that donors may perceive that research on their tissue may lead to a cure for their own cancer, or may confuse the collection of their tumour sample for research with further testing for their own diagnosis and treatment.

Immense anxiety, uncertainty and ontological insecurity characterise the experience of cancer $[40,45]$ and this anxiety may itself be a major motivating force - rallying, propelling and stimulating individuals to act [30]. Patients with cancer may also be motivated by their disease to donate tumour samples because this provides them with at least a symbolic means for 'taking control' of a force that threatens to overwhelm every aspect of their life. (While this desire for agency may be particularly strong in the case of cancer, this motivation to donate is not unique to tumour banking research and may apply to any seriously ill person being asked to participate in research.)

\section{Social Exchange, the Formation of Social Bonds and} the 'Gift Relationship'

In recent years, sociologists have suggested that donation of time, services, organs and tissue may be best understood as a social exchange, or as the giving or receiving of 'gifts' [46, 47]. This is often called the 'gift relationship'. The basic idea is that gifts of blood and tissue may reinforce existing social ties and enrich or create intimate relationships between donors and others, including the patient's health care providers. Patients, therefore, may be motivated to provide tissue both by the desire to please 
their treating physician (and her/his research colleagues) and by the desire to respond to kind acts of health care providers with kindness. In the case of tissue donation, the gift of health care, of diagnosis and treatment elicits another gift of kindness - tissue donation [30]. In the 'shared common universe' of clinical care, tissue donation may therefore strengthen social solidarity with those who provide the donor with treatment and care [48]. In his analysis of motivation, Giddens [49] identifies the desire of social agents to realise trust in their transactions with others as a central motivation. Similarly, Milbank [50] argues that the gift exchange helps form and cement 'primary social bonds' that 'connect and unite' patients with their caregivers. These constructions of tissue donation as a form of social exchange or therapeutic relationship appear to be supported by empirical research by Pilliavin and Callero [51] and Zaller et al. [52]: both found that blood donors are often 'motivated' to donate by personal requests and social pressure.

\section{Possible Motivations to Refuse Donation of Tumour Samples}

While a number of clinical, social and ontological forces may motivate patients to donate their tissue for research, different influences may lead them to refuse consent.

\section{Potential Harms}

It has been suggested that the main concern for those deciding whether to donate their tissue for research is whether their confidentiality will be breached and their personal information (especially genetic information) misused by 'non-scientific' entities including insurance companies and employers $[3,15,16]$. This issue is, however, clearly not one limited to tumour banking, as any research that gives third parties access to personal information raises similar privacy concerns [3]. Likewise, while it has been suggested that concerns about the sale of donated or personal information to, or its use by commercial organisations may be an issue in tissue banking research, this concern also arises in relation to clinical trials (which are often industry sponsored) and in the context of therapeutic 'live' tissue donation, such as in blood donation $[3,15,16]$.

\section{Status of Human Tissue}

In recent years, it has been recognised that the body, and certain tissues in particular, may have specific cul- tural value and that these values may determine the likelihood of donation. In particular, it has been proposed that people from certain religious or ethnic groups may be unwilling to donate tissue because the tissue is in some way sacred or precious to them [13, 53, 54]. Whether the cultural value attached to tissue changes as tissue becomes pathological (cancerous) is an important issue here as this distinguishes the cultural context of tumour banking from other forms of research and from donation for transplantation. If tumour tissue is regarded as waste material or a threat to security or one's wellbeing, and not afforded the status attributed to healthy tissues and organs, then many of the concerns relating to the cultural value of tissue may disappear. The few empirical studies that have examined this question suggest that the nature of the tissue sample, or the way the sample is described discursively, may play a significant part in decisions to donate. The North Cumbria Community Genetics project, for example, which collected placental and umbilical cord tissue, found that mothers who donated reported that their decision was relatively unproblematic as it involved the giving away of 'waste material', material that was normally 'thrown away' [37].

\section{Lack of a Pre-Existing Social Imperative}

The extent to which clinicians and researchers can influence people to donate tissue or organs may depend, in part, on whether they are familiar with, and supportive of, the entity to which their tissue will be donated. This issue becomes clear when one compares tumour donation to therapeutic organ and blood donation. The majority of the public is aware of therapeutic donation and often has considered whether or not they would like to participate in donation. In contrast, tumour banking is a relatively new and abstract phenomenon that is still entering the public consciousness, and most potential tumour donors will not have previously reflected upon whether or not they wish to participate in such research. Thus, when confronted with a request to donate tumour tissue, the patient's attention may be focussed on what is likely to be an unfamiliar object in an otherwise typical (clinical) surrounding. In contrast to therapeutic tissue/ organ donation, patients approached to donate to tumour banks lack the past experiences and 'stocks of interpretive' knowledge that are relevant for decisions to act on a request that they donate tumour tissue [55]. In these situations, patients must discover what tumour banking is, why it is beneficial and how they may contribute. Decisions to donate tissue are therefore likely to be influenced 
strongly by the information that clinicians and researchers provide about the risks and benefits of tumour banking [55].

\section{Perception of Loss of Control}

One key distinction between tissue banking research and other kinds of research and other kinds of therapeutic donation is that tissue may be stored indefinitely [56, 57]. While this provides the very basis of its ongoing benefit, it also raises the possibility of ongoing harms and of unanticipated future harms. In this sense, tumour banking differs from clinical research, where the intervention usually takes place at one point in time and where subjects may have a direct and ongoing relationship with the researchers and are able to withdraw from the research at any time according to their preference and/or their changing perceptions of benefit. In tissue banking research, the subject of interest (the patient's tissue) may be sent offshore and/or provided to third parties, meaning that neither the patient nor the researcher has control over the scientific or commercial use of that tissue. While there is limited evidence that this is a real concern for patients, the perception of loss of control may influence the decision to donate, and certainly drives ever-increasing demand for ongoing contact with donors and for projectspecific consent. This may, in time, be shown to be a genuine issue for patients and their families.

\section{Conclusion}

It is clear that the influences of decisions to donate tissues to tumour banks both overlap with, and differ from, those that influence decisions to participate in clinical research and donate live therapeutic tissues. Like clinical research and live therapeutic donation, the decision to donate tumour tissue may rest on a combination of altruism, egoism and social exchange, but decisions to donate to tumour banks may differ in three main ways: (1) the negative symbolic and linguistic associations of cancer may determine both the degree to which donation is altruistic and perceptions of the integrity or 'sacredness' of tissue; (2) potential donors are likely to be unaware of tumour banking, and so may be less cognisant of its risks and benefits and more susceptible to influence; and (3) as researchers may have ongoing access to banked tissues, both the real and perceived unspecified risks may influence the decisions of donors.

\section{Practical Implications}

There are four major practical implications that result from an awareness of the reasons why people may decide to donate to a tumour bank. The first is the need to explicitly acknowledge the central importance of the relationships between patients and their caregivers/researchers in decisions to donate tissue. The second is the impact that public education about tumour banking research may have on people's reasons for donating. The third is the continuing uncertainty regarding the optimal means for obtaining consent where future research projects may be unanticipated: open-ended consent or project-specific consent. The fourth is the need to explicitly acknowledge how a cancer diagnosis may change the way that potential donors think about donation of the tumour tissue. (As the first three issues are extensively addressed in the literature, they will not be discussed further here.)

It is important that the negative symbolism of the tumour be acknowledged during the consent process for two reasons. First, it is important that patients' desires to be rid of the tumour be validated while at the same time ensuring that patients are not consenting to research simply out of an impulsive, anxious desire to be 'rid' of the tumour. Second, it is important to ensure that patients understand that while their tissue may have no value to them, and may even be repulsive and terrifying, it has potentially great value to medical research. This type of dialogue seems important because it clearly asserts the value of tumour banking research, and because it recognises the value of the patient's 'gift'. If we believe that self-realisation as a result of donation is an outcome that is valued in the clinical and research setting, then tumour donors should be encouraged to recognise the epistemological value of their donation for research, even though the tumour itself may have no value to them.

While review of the motivations that drive participation in clinical research and donation of live therapeutic tissue suggest possible influences on donors to tumour bank, further empirical research is clearly needed to clarify: the extent to which donors trust tumour banks; the impact of open-ended research on the contemporaneous decisions of donors; the extent to which potential tumour donors are swayed by fears of loss of privacy; the degree to which commercial imperatives influence altruism or gift relationships; the extent to which certain populations (e.g. Aboriginal peoples) are motivated by culturally specific symbolism embedded within tumour samples, and the extent to which anxiety surrounding cancer might 
determine decisions to participate in both clinical and tumour banking research.

More generally, more thought needs to be given to the impact of the illness experience and of the social context on patient decisions to donate. Consent processes for tumour banking should take account of the range of potential motives that may influence a patient's decision to donate tissue. This might involve asking patients what they know about tumour banking, what they expect from donating their tissue for research, whether they have any anxieties about donating their tissue, and if so, what they are and how they came to their decision to donate. This will take time, but ultimately it is likely to increase the validity and integrity of the consent process and increase trust in and engagement with biomedical research.

Given the importance of knowledge about tumour banking to decision-making about donation, we argue that issues surrounding tumour banking must enter public discourse much like organ donation and clinical research participation are in the public domain. This will mean that when patients are faced with decisions of whether or not to participate in tumour banking, they will be better equipped with meaning complexes and motivational understanding that are necessary to reflect upon and interpret the situation and what is being asked of them, and to realise their pragmatic interests.

\section{Acknowledgement}

This project was funded by the Cancer Research Fund, University of Sydney, Australia. We are grateful for assistance from Professor Les Bokey.

\section{References}

1 Oosterhuis JW, Coebergh JW, van Veen EB: Tumour banks: well-guarded treasures in the interest of patients. Nat Rev Cancer 2003; 3:73-77.

2 Korn D: Dangerous intersections: new proposals to protect genetic privacy may collide with the public interest in fostering medical research. Issues Sci Technol 1996;13:55-62.

3 Australian Law Reform Commission: Essentially Yours: The Protection of Human Genetic Information in Australia (ALRC96). Canberra, Commonwealth of Australia, 2003.

4 National Health and Medical Research Council: National Statement on Ethical Conduct in Research Involving Humans. Canberra, Commonwealth of Australia, 1999.

5 Walker B: Inquiry into Matters Arising from the Post-Mortem and Anatomical Practices of the Institute of Forensic Medicine. Sydney, New South Wales Government, 2001.

6 The Royal Liverpool Children's Inquiry Report (The Redfern Report), London, Stationary Office, 2001.

7 Savulescu J: No consent should be needed for using leftover body material for scientific purposes. Against. BMJ 2002;325:648-651.

$>8$ Bauer K, Taub S, Parsi K: Ethical issues in tissue banking for research: a brief review of existing organizational policies. Theor Med Bioeth 2004;25:113-142.

9 Trouet C: New European guidelines for the use of stored human biological materials in biomedical research. J Med Ethics 2004;30: 99-103.

10 Dickenson D: Commodification of human tissue: implications for feminist and development ethics. Dev World Bioeth 2002;2: 55-63.
11 Zodrow JJ: The commodification of human body parts: regulating the tissue bank industry. Southwest Univ Law Rev 2003;32:407449.

12 Jack AL, Womack C: Why surgical patients do not donate tissue for commercial research: review of records. BMJ 2003;327: 262.

13 Campbell C: Research on Human Tissue: Religious Perspectives: Research Involving Human Biological Materials: Ethical Issues and Policy Guidance, vol II. Rockville, National Bioethics Advisory Committee, 2000, pp C-1-C-22.

14 Zeps N: Ethics and logistics of using archival pathology material. Cancer Forum 2003;27: 108-110.

15 Hoeyer K, Olofsson BO, Mjorndal T, Lynoe $\mathrm{N}$ : The ethics of research using biobanks: reason to question the importance attributed to informed consent. Arch Intern Med 2005; 165:97-100.

-16 Hoeyer K, Olofsson BO, Mjorndal T, Lynoe $\mathrm{N}$ : Informed consent and biobanks: a population-based study of attitudes towards tissue donation for genetic research. Scand J Public Health 2004;32:224-229.

17 Hoeyer K: 'Science is really needed - that's all I know': informed consent and the nonverbal practices of collecting blood for genetic research in northern Sweden. New Genet Soc 2003;22:229-244.

18 Wendler D, Emanuel E: The debate over research on stored biological samples: what do sources think? Arch Intern Med 2002;162: 1457-1462.
19 Goodson ML, Vernon BG: A study of public opinion on the use of tissue samples from living subjects for clinical research. J Clin Pathol 2004;57:135-138.

20 Porter T: Public Perceptions of the Collection of Human Biological Samples. Report prepared for the Medical Research Council and the Wellcome Trust. London, Craig Ross Dawson, 2000.

21 Ring L, Lindblad A: Public and patient perception of biobanks and informed consent; in Hansson MG, Levin M (eds): Biobanks as Resources for Health. Uppsala, Research Program Ethics in Biomedicine, 2003.

22 Stegmayr B, Asplund K: Informed consent for genetic research on blood stored for more than a decade: a population based study. BMJ 2002;325:634-635.

23 Nilstun T, Hermeren G: Human tissue samples and ethics - attitudes of the general public in Sweden to biobank research. Med Health Care Philos 2006;9:81-86.

24 Mills C: Situated actions and vocabularies of motive. Am Sociological Rev 1940, pp 904909.

25 Schutz A: Phenomenology and Social Relations. London, Heinemann Educational Books, 1976.

26 Blum AF, McHugh P: The social ascription of motives. Am Sociol Rev 1971;36:98-109.

27 Smelser NJ, Smelser WT: Personality and Social Systems. New York, Wiley, 1963.

28 The New Oxford Dictionary of English. Oxford, Oxford University Press, 1998.

29 Lipworth W: Generating a taxonomy of regulatory responses to emerging issues in biomedicine. J Bioeth Inq 2005;2:130-141. 
-30 Cox K, Avis M: Psychosocial aspects of participation in early anticancer drug trials: report of a pilot study. Cancer Nurs 1996;19: 177-186.

- 31 Knoppers BM, Laberge CM: Research and stored tissues: persons as sources, samples as persons? JAMA 1995;274:1806-1807.

32 Fallowfield LJ, Jenkins V, Brennan C, Sawtell M, Moynihan C, Souhami RL: Attitudes of patients to randomised clinical trials of cancer therapy. Eur J Cancer 1998;34:15541559.

-33 Wilson P, Sexton W, Singh A, Smith M, Durham S, Cowie A, Frischi L: Family experiences of tissue donation in Australia. Prog Transplant 2006;16:52-56.

-34 Schwartz SH: Elicitation of moral obligation and self-sacrificing behavior: an experimental study of volunteering to be a bone marrow donor. J Pers Soc Psychol 1970;15:283-293.

35 Simmons RG, Schimmel M, Butterworth VA: The self-image of unrelated bone marrow donors. J Health Soc Behav 1993;34:285301.

36 Nurgat ZA, Craig W, Campbell NC, Bissett JD, Cassidy J, Nicolson MC: Patient motivations surrounding participation in phase I and phase II clinical trials of cancer chemotherapy. Br J Cancer 2005;92:1001-1005.

37 Barr M: 'I'm not really read up on genetics': biobanks and the social context of informed consent. BioSocieties 2006;1:251-262.

- 38 Fielding D, Handley S, Duqueno L, Weaver S, Lui S: Motivation, attitudes and experience of donation: a follow-up of women donating eggs in assisted conception treatment. J Community Appl Soc Psychol 1998;8:273287.
39 Prottas JM: Encouraging altruism: public attitudes and the marketing of organ donation. Milbank Mem Fund Q Health Soc 1983;61: 278-306.

40 Sontag S: Illness as Metaphor. New York, Farrar, Strauss \& Giroux, 1977.

41 Boe GP, Ponder LD: Blood donors and nondonors: a review of the research. Am J Med Technol 1981;47:248-253.

42 Edwards SJ, Lilford RJ, Hewison J: The ethics of randomised controlled trials from the perspectives of patients, the public, and healthcare professionals. BMJ 1998;317:12091212.

43 Lidz CW, Appelbaum PS, Grisso T, Renaud M: Therapeutic misconception and the appreciation of risks in clinical trials. Soc Sci Med 2004;58:1689-1697.

44 Appelbaum PS, Roth LH, Lidz CW, Benson P, Winslade W: False hopes and best data: consent to research and the therapeutic misconception. Hastings Cent Rep 1987;17:2024.

45 Mills EJ, Seely D, Rachlis B, Griffith L, Wu P, Wilson K, Ellis P, Wright JR: Barriers to participation in clinical trials of cancer: a metaanalysis and systematic review of patientreported factors. Lancet Oncol 2006;7: 141-148.

46 Maus M: The Gift: The Form and Reason for Exchange in Archaic Societies. London, Routledge, 1990.
47 Titmuss RM: The gift relationship: From human blood to social policy. London, London School of Economics Books, 1970.

48 Garfinkel H: Studies in ethnomethodology. Englewood Cliffs, Prentice-Hall, 1967.

49 Giddens A: The Constitution of Society: Outline of a Theory of Stratification. Berkeley, University of California Press, 1984.

50 Milbank J: The gift and the given. Theor Cult Soc 2006;23:444-447.

51 Pilliavin J, Callero P: Giving Blood: The Development of an Altruistic Identity. Baltimore, Johns Hopkins University Press, 1992.

52 Zaller N, Nelson KE, Ness P, Wen G, Bai X, Shan H: Knowledge, attitude and practice survey regarding blood donation in a northwestern Chinese city. Transfus Med 2005; 15 : 277-286.

53 Eriksson S, Helgesson G: Potential harms, anonymization, and the right to withdraw consent to biobank research. Eur J Hum Genet 2005;13:1071-1076.

54 Rothstein MA: Expanding the ethical analysis of biobanks. J Law Med Ethics 2005;33: 89-101.

55 Schutz A: Reflections on the Problem of Relevance. New Haven, Yale University Press, 1970.

56 Beskow LM, Burke W, Merz JF, Barr PA, Terry S, Penchaszadeh VB, Gostin LO, Gwinn M, Khoury MJ: Informed consent for population-based research involving genetics. JAMA 2001;286:2315-2321.

57 Salter B, Jones M: Biobanks and bioethics: the politics of legitimation. J Eur Pub Pol 2005; $12: 710-732$. 